\title{
EFFECT OF PHOSPHORUS AND SULPHUR ON PRODUCTIVITY OF CHICKPEA (CICER ARIETINUM L.) UNDER NEW VALLEY CONDITIONS
}

\author{
Shoman, Hosam A. \\ Agronomy Unit, Department of Plant Production, Desert Research \\ Center, El-Matareya, Cairo, Egypt \\ E-mail: dr_hosam_shoman@yahoo.com
}

$\mathrm{F}$

ield experiments were conducted for two years at the Desert Research Center (DRC), Agricultural Experimental Station at El-Kharga Oasis, New Valley Governorate, South Western, Egypt, during two winter growing seasons of 2015/ 2016 and 2016/2017. This work aimed to study the effect of phosphoric acid foliar application levels of $0,0.5,1,1.5$ and $2 \mathrm{~L} /$ feddan ( 0.42 hectar) and sulphur fertilizer at rates of $0,50,100,150$ and $200 \mathrm{~kg} \mathrm{~S} /$ feddan on the yield and quality of chickpea in alkaline soils. Experimental results revealed that yield and quality of chickpea were significantly influenced by phosphorus foliar application, except seed $\mathrm{K}$ and $\mathrm{S} \%$, which were not significantly affected in both seasons. The maximum values of these parameters were produced by $1 \mathrm{~L} /$ feddan. Phosphorus $(\mathrm{P})$ foliar in both seasons as compared with nil $\mathrm{P}$ (control), 1.5 and $2 \mathrm{~L} /$ feddan, except $\mathrm{P} \%$ in seeds was increased with the increase of spraying level of $\mathrm{P}$ from 0 to $2 \mathrm{~L} /$ feddan in both seasons. The results showed that increasing sulphur fertilization rates from 0 to $200 \mathrm{~kg} \mathrm{~S} /$ feddan caused a significant increase in all yield components and seed chemical composition of chickpea plants under this study in the both seasons. The highest values were obtained at $200 \mathrm{~kg} \mathrm{~S} /$ feddan compared with control treatment (without sulphur fertilizer), this is fairly true in both seasons. Yield and quality of chickpea were significantly affected by the interaction between phosphorus foliar application and sulphur fertilizer. While, percentages of phosphorus, potassium and sulphur in seeds have not been affected significantly by the interaction in both seasons.

Keywords: Chickpea, sulphur, phosphorus, yield, chemical composition

Chickpea (Cicer arietinum L.), a member of family Fabaceae, is an ancient self-pollinated leguminous crop, diploid annual (2 $\mathrm{N}=16$ chromosomes) grown since $7000 \mathrm{BC}$, in different area of the world. 
Archaeological records bestow information that the cultivated chickpea was the first grain legume to be domesticated in the old World. Average chickpea yield in Egypt is much lower than in developed countries of the world. Many factors restrict the cultivation of chickpeas under the conditions of many Egyptian lands, including the limited elements needed during the growth period; such as phosphorus, sulfur and some micronutrients as a result of the relatively, high soil $\mathrm{pH}$, which reduces the productivity. Under these cases, it should be searched for any solutions for these obstacles in these areas. There are promising newly reclaimed lands in Egypt, in this respect, one of the most suitable locations is New Valley region with its Oases, which represents large land resources and a good hope for agriculture expansion, which is located at the Western Desert of Egypt, since it represents 38\% $\left(376000.51 \mathrm{~km}^{2}\right)$ of the total area of Egypt and has about 3.5 million feddan (0.42 hectar) available for cultivation. But a large part of these lands suffer from high alkalinity, which caused many problems, the most important of which is the unavailability of many nutrients in the rhizosphere, especially phosphorus. Phosphorus (P) and sulphur (S) are major nutrient elements for grain legumes. In many soil types, $\mathrm{P}$ is the most limiting nutrient for the production of crops (Jiang et. al., 2006). It plays a primary role in many of the physiological processes, such as the utilization of sugar and starch, photosynthesis, energy storage and transfer. Legumes generally have higher $\mathrm{P}$ requirement because the process of symbiotic nitrogen $(\mathrm{N})$ fixation consumes a lot of energy (Schulze et al., 2006).

Whereas, $\mathrm{P}$ fertilizer use is very inefficient in agriculture and its recovery is estimated to be between $10-15 \%$ of the $\mathrm{P}$ applied (Syers and Curtis, 2008), in alkaline soils, $P$ will react with calcium $(\mathrm{Ca})$ forming hydroxyapatite, dicalcium and octacalcium phosphates, all of which are very insoluble, and decrease the availability for plants (Lindsay et al., 1989). Phosphorus is a key element involved in various functions in growth and metabolism of pulses. It is frequently a major limiting nutrient for plant growth in most soils. Only a part of $\mathrm{P}$ supplemented through fertilizer is utilized by the plants and a large portion of it is converted into insoluble fixed forms in alkaline soils, the recovery efficiency of $\mathrm{P}$ in crops is generally $10-30 \%$ (Swarup, 2002). Therefore, the utilization of $\mathrm{P}$ as a foliar application becomes increasingly important. The mechanistic processes by foliar applied indicate that nutrients are taken up through leaf stomata (Eichert and Burkhardt, 1999) and hydrophilic pores within the leaf cuticle (Tyree et al., 1990). This can be addressed through the use of $\mathrm{P}$ by spraying on the plant instead of adding to the soil. Phosphorus is one of the most important nutrients for chickpea (Cicer arietinum L.) and contributes directly to both the yield and quality of it, so it has often been called the "Master key of Agriculture".

Sulphur is one of the most important solutions that contribute directly in overcoming the problems of alkaline soils and the lack of the availability

Egyptian J. Desert Res., 67, No. 2, 305-318 (2017) 
of many elements in these soils such as, $\mathrm{P}, \mathrm{Fe}, \mathrm{Zn}, \mathrm{Cu}, \mathrm{Mo}, \mathrm{B}$ and $\mathrm{Mn}$. In addition, $\mathrm{S}$ is now recognized as major plant nutrient, along with nitrogen $(\mathrm{N})$, P, and potassium $(\mathrm{K})$. It is essential for the growth and development of all crops, without exception. Most of the plants requirement of $\mathrm{S}$ is absorbed through the roots in the form of sulphate $\left(\mathrm{SO}_{4}{ }^{-2}\right)$. Each year, $\mathrm{S}$ deficiency is becoming critical, restricting crop more yield and nutrient use efficiency. Like any essential nutrient, $\mathrm{S}$ also has certain specific functions to perform in the plant. Thus, $\mathrm{S}$ deficiencies can be corrected by the application of $\mathrm{S}$ fertilizer (Tondon and Messick, 2007). This study was conducted in order to study the effect of different doses of $\mathrm{P}$ as a foliar and $\mathrm{S}$ application on some yield components and chemical composition in chickpea plant grown in alkaline soils.

\section{MATERIALS AND METHODS}

Two field experiments were carried out in the Desert Research Center (DRC), Agricultural Experimental Station at El-Kharga Oasis, New Valley Governorate, during the two winter growing seasons of 2015/ 2016 and 2016/2017. The study inquired into the effect of phosphoric acid foliar at levels of $0,0.5,1,1.5$ and $2 \mathrm{~L} /$ per feddan and $\mathrm{S}$ fertilizer at rates of 0,50 , 100,150 and $200 \mathrm{~kg} \mathrm{~S}$ per fedsan on the yield and chemical composition of chickpea. Whereas, the spraying of $\mathrm{P}$ was in the form phosphoric acid $85 \%$ and was done five times during growing season, first after one month from planting and then every 15 days. Sulphur fertilization was in the form agricultural $\mathrm{S}$ and was added during the preparation of soil for planting. Soil samples collected were analyzed for mechanical and chemical analysis. Soil $\mathrm{pH}$ of experimental site was found to be vary from 8.73 to 8.67 , while EC617 to $589 \mathrm{ppm}$, organic matter- 0.54 to $0.59 \%$, available N- 62 to $67 \mathrm{ppm}$, available P- 0.49 to $0.53 \mathrm{ppm}$, available K- 29 to $33 \mathrm{ppm}$ and available S2.27 to 3.11 . Soil samples analyzed was found to be of sandy clay loam texture.

The experiment included 25 treatments which were the combinations between the five levels of phosphoric acid foliar application and five rates of $\mathrm{S}$ fertilizer The experimental design was split plots design with three replicates, five levels of phosphoric acid foliar application (spraying with water only as a control) were assigned in the main plots and five rates of $\mathrm{S}$ fertilizer were randomly distributed in the sub plots. NPK fertilizers were added at the rate of $15 \mathrm{~kg} \mathrm{~N} /$ fedsan as ammonium nitrate $33 \% \mathrm{~N}, 50 \mathrm{~kg}$ /fedsan as calcium super phosphate $\left(15.5 \% \mathrm{P}_{2} \mathrm{O}_{5}\right)$ and $50 \mathrm{~kg} \mathrm{~K}_{2} \mathrm{O} /$ feddan $(48 \%)$ as potassium sulfate, respectively and were added during the seedbed preparation. Chickpea seeds Giza- 88 cultivar were planted on the last week of November in the two seasons, after inoculated with rhizobium strain and irrigated just after sowing. The experimental unit area was $10.5 \mathrm{~m}^{2}$ consisting of fifteen rows ( $3.5 \mathrm{~m}$ long and $0.20 \mathrm{~m}$ between rows), $0.20 \mathrm{~m}$ between hills. Drib irrigation was applied during the two seasons. The 
normal agronomic practices of growing chickpea in this district were practiced till harvest as recommended. At harvest, five guarded plants at random from the middle ridges of every plot were taken after 103 and 107 days from sowing in the two growing seasons, respectively, to determine the following characters: plant height $(\mathrm{cm})$, number of branches /plant, number of bods /plant, 100 seed weight $(\mathrm{g})$, seed yield $(\mathrm{kg} /$ feddan) and harvest index $\%$. As well as, in seeds: protein (\%), carbohydrates (\%), N (\%), P (\%), K (\%) and $\mathrm{S}(\%)$, at harvest seed yield $(\mathrm{kg})$ of each plot were recorded and then transformed into yield ( $\mathrm{kg}$ / feddan). Harvest index was measured by dividing seed yield/feddan on biological yield/feddan $X$ 100. Protein and carbohydrate percentages in seeds were determined by infratec1241 Grain Analyzer. All the obtained data were subjected to analysis of variance according to the method described by Gomez and Gomez (1984). Means comparison were done using least significant difference (LSD) at 5\% level of probability.

\section{RESULTS AND DISCUSSION}

\section{Effect of Phosphoric Acid Foliar Application}

Table (1) shows the effect of different levels of foliar P in the form of phosphoric acid on some of yield components and seed chemical composition of chickpea, i.e. plant height $(\mathrm{cm})$, number of branches/plant, number of bods/plant, 100 seed weight $(\mathrm{g})$, seed yield $(\mathrm{kg} /$ feddan), harvest index (\%), N (\%), P (\%), K (\%), S (\%), carbohydrates (\%) and protein (\%) under alkaline soils at New Valley. Data showed that applying P spray levels from zero to $2 \mathrm{~L} /$ feddn to chickpea caused a significant increase in all these parameters, except seed $\mathrm{K}$ and $\mathrm{S} \%$, which were not significantly affected by $\mathrm{P}$ foliar application in both seasons. While, the differences between $\mathrm{P}$ foliar application by 1 and $1.5 \mathrm{~L} /$ feddan had insignificant effect on number of branches/plant only in the two seasons. Maximum values of these parameters were produced by $1 \mathrm{~L} /$ feddan of $\mathrm{P}$ foliar in both seasons as compared with nil $\mathrm{P}$ (control) and the rest levels, except $\mathrm{P} \%$ in seeds was increased with the increase of spraying level of $\mathrm{P}$ from 0 to $2 \mathrm{~L} /$ feddan in both seasons. The increasing percentages outcome the foliar application of $\mathrm{P}$ by $1 \mathrm{~L} /$ feddan compared with control for plant height were 55.69 and 56.95; number of branches /plant were 85.65 and 77.38; number of bods /plant were 48.17 and $47.46 ; 100$ seed weight were 47.52 and 49.82 ; seed yield were 30.86 and 32.09; harvest index were 14.38 and 12.48; $\mathrm{N} \%$ were 35.68 and 35.91; carbohydrates were 9.45 and 9.59 and protein were 36.32 and $35.89 \%$ in the first and second seasons, respectively. The increasing percentages outcome of the foliar application of $\mathrm{P}$ by $2 \mathrm{~L} /$ feddan for $\mathrm{P} \%$ in seeds compared with control were 159.09 and $160.87 \%$ in the first and second seasons, respectively. 


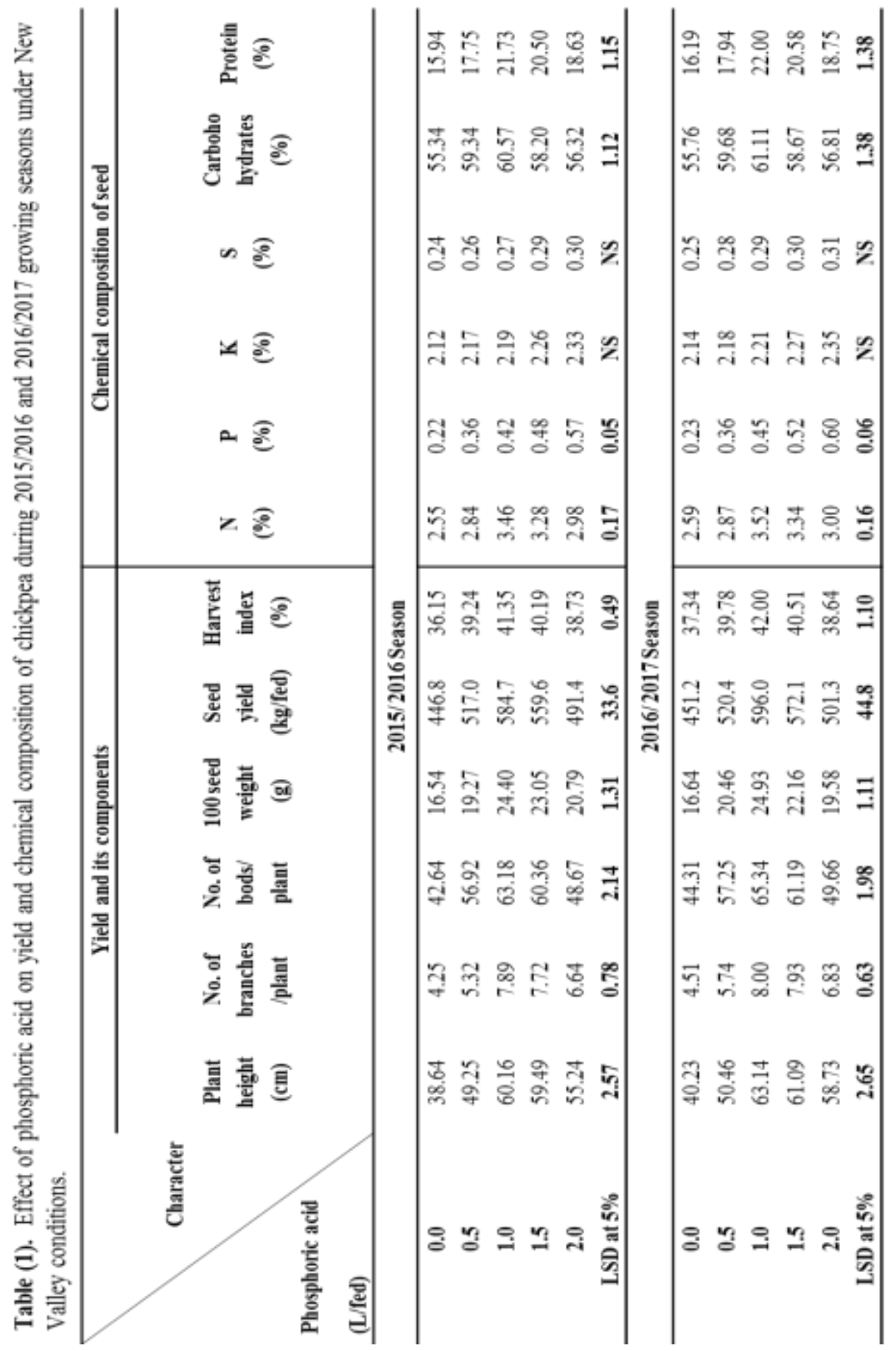

Egyptian J. Desert Res., 67, No. 2, 305-318 (2017) 
Results indicated that foliar application of $\mathrm{P}$ at $1 \mathrm{~L} /$ feddan is a quite enough to achieve the highest values of the studied parameters under the current experiment. Where, spray of $\mathrm{P}$ at a rate higher than $1 \mathrm{~L} /$ feddan resulted in a significant decrease in all studied parameters values due to burning of plant leaves, which observed during the growing seasons as a result of the increase in rates of spraying, which negatively affected on the plant growth rate. The good effect of phosphorus on the plant growth is due to that phosphorus enhanced development of meristematic tissue, number of flower buds, photosynthetic activity, biosynthesis of chlorophyll, mobilization of photosynthates, photosynthetic $\mathrm{CO}_{2}$ fixation, cell division, and carbohydrate metabolism. These results agree with those obtained by Syers and Curtis (2008), Basir et al. (2008), Islam et al. (2011), Ryan et al. (2012), Singh and Singh (2012), Dotaniya et al. (2014) and Saeed et al. (2017).

\section{Effect of Sulphur Fertilizer}

Data in table (2) reveal that increasing $\mathrm{S}$ fertilization rates from 0 to $200 \mathrm{~kg} \mathrm{~S} /$ feddan caused a significant increase in all yield components and seed chemical composition of chickpea plants under this study, in the both seasons. The highest values of plant height $(\mathrm{cm})$, number of branches/plant, number of bods/plant, 100 seed weight $(\mathrm{g})$, seed yield $(\mathrm{kg} /$ feddan), harvest index (\%), N (\%), P (\%), K (\%), S (\%), carbohydrates (\%) and protein (\%) were obtained at $200 \mathrm{~kg} \mathrm{~S} /$ feddan, compared with control treatment (without $\mathrm{S}$ fertilizer) in both seasons. The increasing percentages attribute with using the high rate of $\mathrm{S}$ ( $200 \mathrm{~kg} \mathrm{~S} /$ feddan), as comparing with control treatment, for plant height $(\mathrm{cm})$ were 87.20 and 84.35 ; number of branches/plant were 96.21 and 96.92; number of bods /plant were 75.33 and 77.84; 100 seed weight $(\mathrm{g})$ were 73.76 and 74.93 ; seed yield $(\mathrm{kg} /$ feddan) were 43.75 and 44.74; harvest index (\%) were 36.18 and 34.36; N seeds (\%) were 59.49 and 60.58 ; P seeds (\%) were 107.41 and 103.57 ; K seeds (\%) were 30.16 and 30.59 ; S seeds were 86.36 and 87.50 , carbohydrates seeds (\%) were 21.37 and 19.13 and protein seeds (\%) were 59.55 and 60.62 in the first and second seasons, respectively.

The results indicated that $\mathrm{S}$ has improved the growth rate and yield of chickpea under alkaline soil condition, because availability of nutrients in soils depends on soil acidity, where availability becomes more by decreasing $\mathrm{pH}$. On the contrary, high $\mathrm{pH}$ results in unavailability of many nutrients including phosphorus, iron, zinc, manganese, copper and other nutrients as well as, poor soil construction and permeability, which negatively effects on plant growth in these soils. Previous studies indicated that $\mathrm{S}$ application in alkaline soils reduced $\mathrm{pH}$ levels and increased $\mathrm{SO}_{4}$ content, furthermore, increased the availability of more nutrients in rhizosphere (Abrol, 1990; Lopez et al., 1999 and Stamford et al., 2002). studies refer to role of S in increasing growth and yield of pulses besides, its involvement in various

Egyptian J. Desert Res., 67, No. 2, 305-318 (2017) 
metabolic and enzymatic process including photosynthesis, respiration and legume-rhizobium symbiotic nitrogen fixation and is required in the formation of protein, vitamins and enzymes and it's a constituent of amino acids, viz., cystine, cystein and methionine (Rao et al., 2001). This finding is in agreement with those obtained by Kumar et al. (2003), Jaggi et al. (2005), Skwierawska et al. (2008), Khan et al. (2011), Nawange et al. (2011), Islam (2012), Mohammad et al. (2012), George (2017) and Kala et al. (2017).

\section{Effect of the Interaction between Phosphoric Acid Foliar Application and Sulphur Fertilizer}

Results in tables (3 and 4) indicate that plant height $(\mathrm{cm})$, number of branches/plant, number of bods/plant, 100 seed weight $(\mathrm{g})$, seed yield $(\mathrm{kg} /$ feddan), harvest index (\%), N (\%), carbohydrates (\%) and protein (\%) were significantly affected by the interaction between $\mathrm{P}$ foliar application and $\mathrm{S}$ fertilizer. While, percentages of $\mathrm{P}, \mathrm{K}$ and $\mathrm{S}$ in seeds have not been affected significantly by the interaction in both seasons. Maximum increments for yield and its components and seed chemical composition of chickpea plants under this study were obtained by spraying chickpea plants by $1 \mathrm{~L} /$ feddan phosphoric acid with $200 \mathrm{~kg} \mathrm{~S} /$ feddan in both seasons. In this respect, the lowest values were achieved by the control treatment for the two factors ( $\mathrm{P}$ and $\mathrm{S}$ ) in the two seasons. The increasing percentages attributes due to spraying of $1 \mathrm{~L}$ phosphoric acid/ feddan and $200 \mathrm{~kg} \mathrm{~S} /$ feddan as comparing with control treatment for plant height $(\mathrm{cm})$ were 70.94 and 72.77 , number of branches/plant were 97.49 and 86.59 , number of bods/plant were 60.87 and $61.58,100$ seed weight $(\mathrm{g})$ were 59.83 and 61.71 , seed yield $(\mathrm{kg} /$ feddan) were 43.74 and 44.84 , harvest index (\%) were 24.96 and $23.04, \mathrm{~N}$ (\%) were 47.15 and 48.00; carbohydrates (\%) were 15.19 and 14.20 and protein (\%) were 47.46 and 47.79 in the first and second seasons, respectively. Saeed et al. (2017) found that the spraying of chickpea plants with different concentrations of phosphoric acid had a significant effect on the yield and its components. The pods yield increased by $46 \%$ when spraying at $1 \mathrm{~L} /$ feddan phosphoric acid, while the concentration of $3 \mathrm{~L} /$ feddan resulted in burning the edges of the leaves due to which final yield was decreasing. The increase in the productivity of chickpea could be attributed to role played by $\mathrm{S}$ in the formation of disulphide linkages, which are associated with structural characteristic of the protoplasm (Kala et al., 2017). Application of $S$ with $P$ have systematic and antagonistic effect with each other on their varying levels, maintain favorable balance between the applied nutrient in the plant for its optimum growth and had effect on metabolism (Biswas and Tewatia, 2016). 


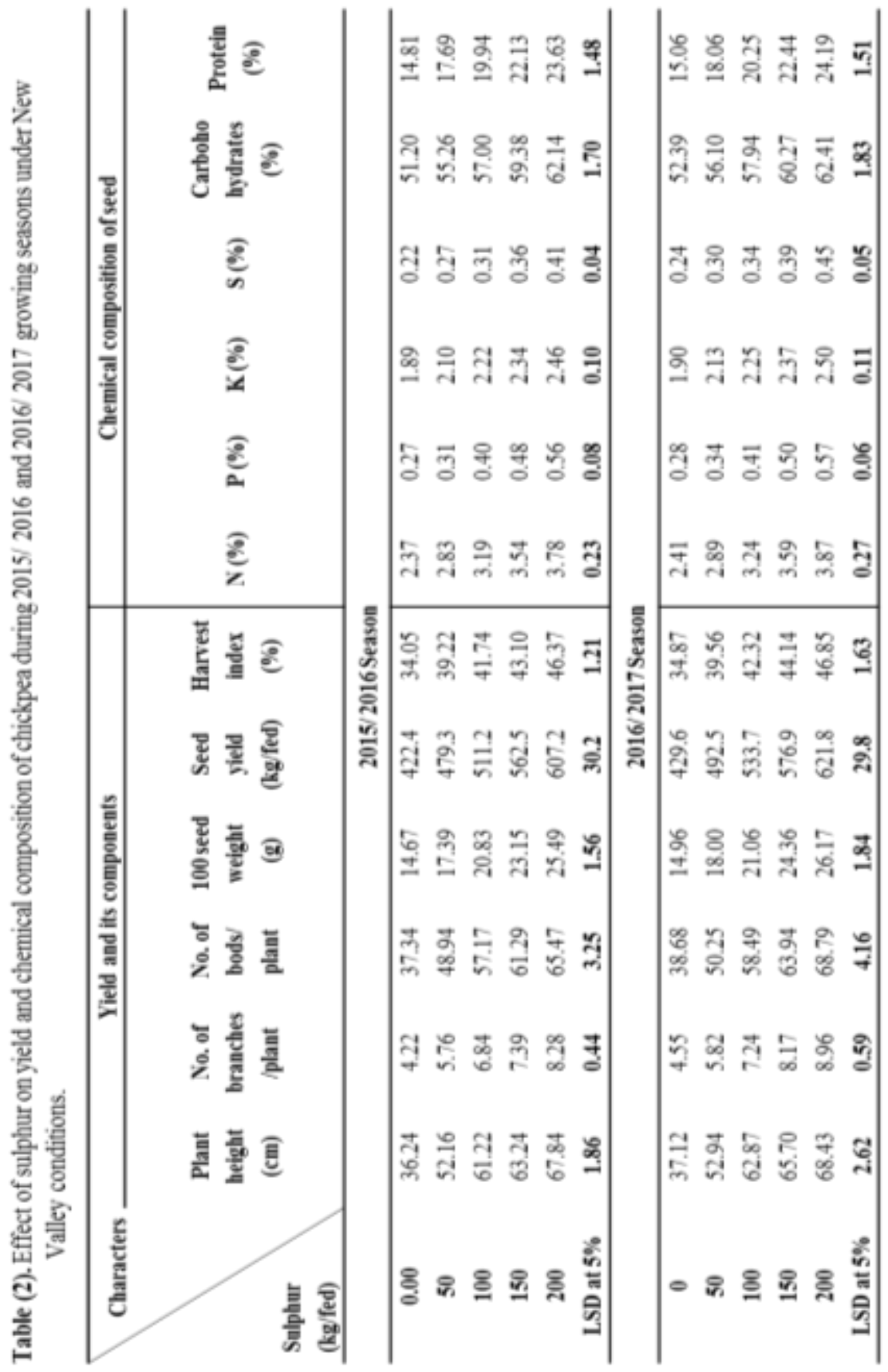

Egyptian J. Desert Res., 67, No. 2, 305-318 (2017) 


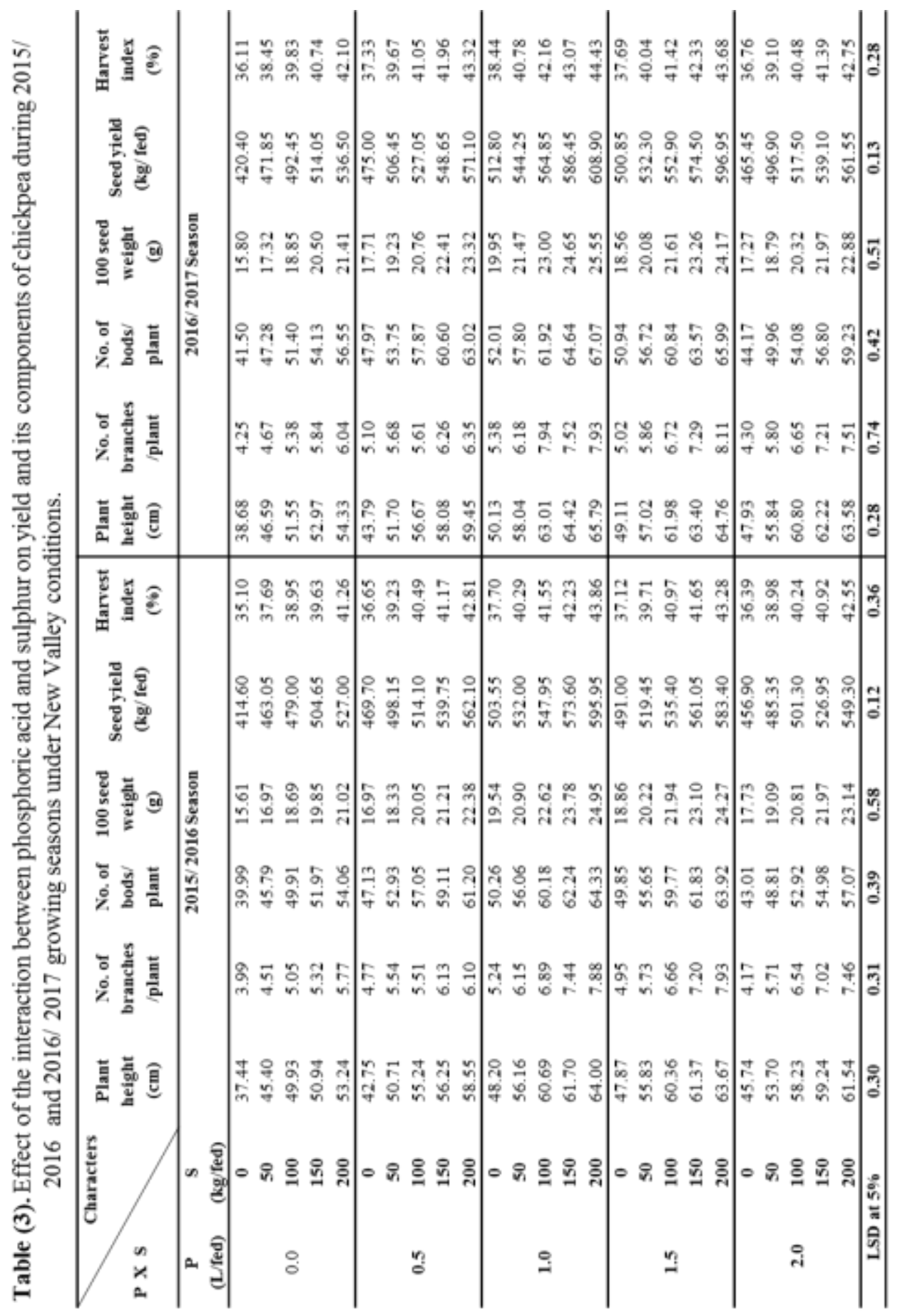

Egyptian J. Desert Res., 67, No. 2, 305-318 (2017) 


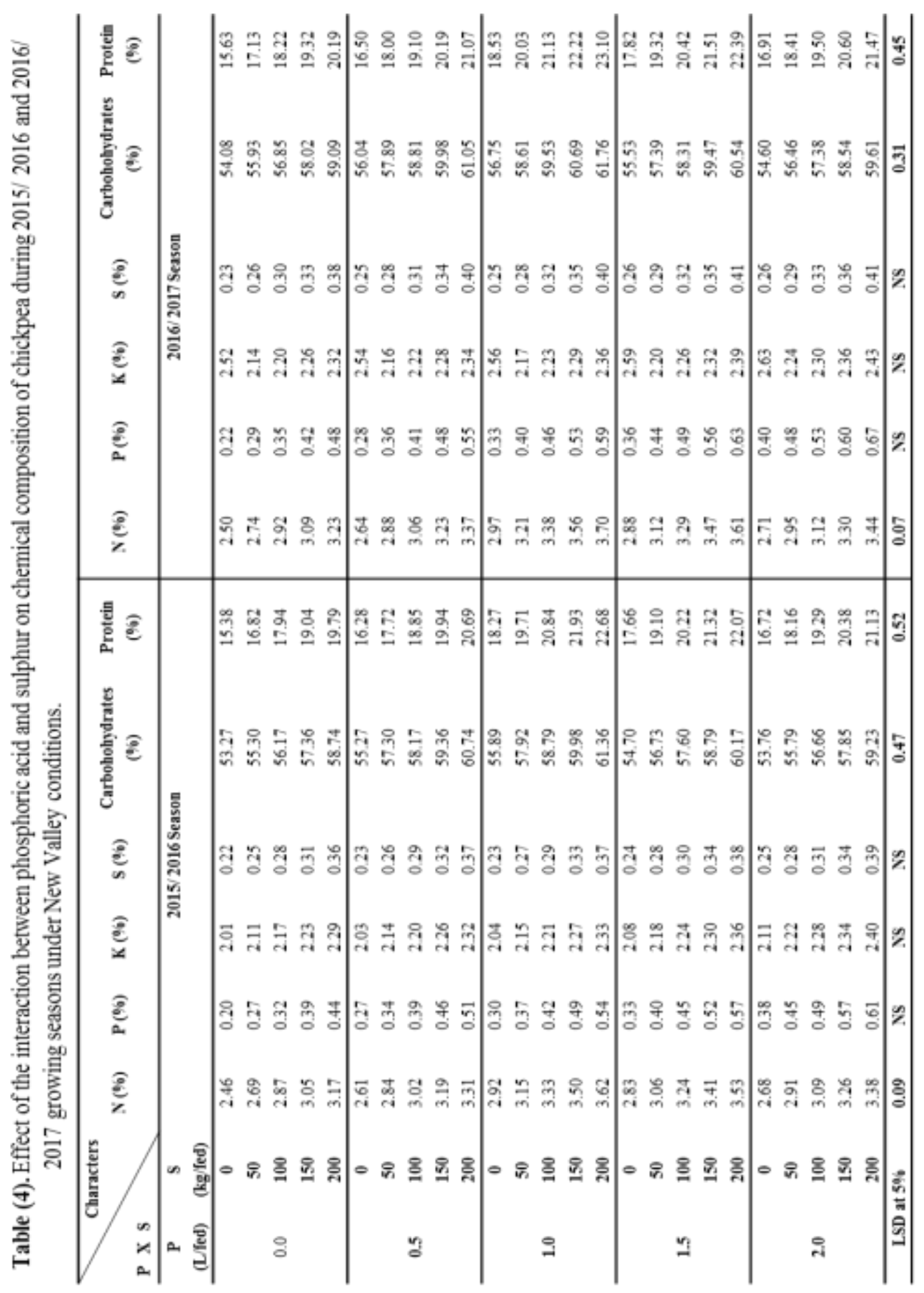

Egyptian J. Desert Res., 67, No. 2, 305-318 (2017) 


\section{REFERENCES}

Abrol, I.P. (1990). Acidity-affected soils and their management. Int. J. Environ. Sci. Tech., 3 (1): 167-172.

Basir, A., Z. Shah, M. Naeem, J. Bakht and Z.H. Khan (2008). Effect of phosphorus and farmyard manure on agronomic traits of chickpea (Cicer arietinum L.). Sarhad J. Agric., 24 (4): 567-572.

Biswas, B.C. and R.K. Tewatia (2016). Nutrient balance in agroclimatic region of India-an overview. Fertilizer News, 36: 13-17.

Dotaniya, M.L., K.K. Pingoliya, M.A. Lata, R. Verma, K.L. Regarn and C.K. Dotaniya (2014). Role of phosphorus in chickpea (Cicer arietinum L.) production. African Journal of Agricultural Research, 9 (51): 3736-3743.

Eichert, T.J. and J. Burkhardt (1999). In "Technology and Applications of Foliar Fertilizers". The Soil and Fertilizer Society of Thailand, pp. 41-54.

George, W.T. (2017). In "Sulphur, A Soil Corrective and Soil Builder". College of Agriculture, University of Arizona (Tucson, AZ) Bulletin, 201.

Gomez, K.A. and A.A. Gomez (1984). In "Statistical Procedures for Agriculture Research". A Wiley-Inter Science Publication, John Wiley and Sons, Inc. New York, USA.

Islam, M. (2012). The effect of different rates and forms of sulfur on seed yield and micronutrient uptake by chickpea. Plant, Soil Env., 58 (9): 399-404.

Islam, M.S., S. Mohsan, S. Afzal, M.A. Akmal and R. Khalid (2011). Phosphorus and sulfur application improves the chickpea productivity under rainfed conditions. Int. J. Agric. Biol., 13: 713718.

Jaggi, R.C., M.S. Aulakh and A. Sharma (2005). Impacts of elemental S applied under various temperature and moisture regimes on $\mathrm{pH}$ and available $\mathrm{P}$ in acidic, neutral and alkaline soils. Biol. Fertil. Soils, 41: 52-58.

Jiang, D., H. Hengsdijk, T.B. Dai, W. Boer, Q. Jing and W.X. Cao (2006). Long term effect of manure and inorganic fertilizer on yield and soil fertility for a winter wheat-maize system in Jiangsu, China. Pedosphere, 16: 25-32.

Kala, D.C., R.N. Dixit, S.S. Meena, G. Nanda and R. Kumar (2017). Effect of graded doses of sulphur and boron on yield attributes and nutrient uptake by chickpea. Int. J. Curr. Microbiol. App. Sci., 6 (6): 55-60.

Khan, M.A., T.K. Verma and S. Singh (2011). Production efficiency of chickpea as affected by inoculation, phosphorus levels and intercropping. J. Agric. Sci., 81: 145-149. 
Kumar, N., S.S. Khangarot and R.P. Meena (2003). Effect of sulphur and plant growth-regulators on yield and quality parameters of chickpea (Cicer arietinum L.). Ann. Agric. Res., 24 (2): 434-436.

Lindsay, S., J.A. Duke and K. Wahala (1989). Phosphorus in soil. J. Nutritional Biochem., 9: 193-200.

Lopez, J.G., F. Larios, G. Gonzalez, M. Rosales and J.R. Freitas (1999). Effect of sulfur application on chemical properties and microbial populations in a tropical alkaline. Pedobiologia, 43: 183-191.

Mohammad, R.D., S. Hemmaty and L. Naseri (2012). Effects of sulfur application on soil $\mathrm{pH}$ and uptake of phosphorus, iron and zinc in apple trees. Journal of Plant Physiology and Breeding, 2 (1): 1-10.

Nawange, D.D., A.S. Yadav and R.V. Singh (2011). Effect of phosphorus and sulphur application on growth, yield attributes and yield of chickpea (Cicer arietinum L). Legume Res., 34 (1): 48-50.

Rao, C.H., Srinivasa, K.K. Singh and A. Masood (2001). Sulphur a key nutrient for higher pulse production. Fertilizer News, 46 (10): 37-38.

Ryan, J., H. Ibrikci, A. Delgado, J. Torrent, R. Sommer and A. Rashid (2012). Significance of phosphorus for agriculture and the environment in the West Asia and North Africa Region. Advances in Agronomy, 114: 91-153.

Saeed, U., J. Amanulla, M. Aly, A. Ahmad, U. Amirm, Gahmad, M. Ishaq and R. Ayesha (2017). Effect of phosphorus and zinc under different application methods on yield attribute of chickpea (Cicer arietinum L.). International Journal of Agricultural and Environmental Research, 3 (1): 79-85.

Schulze, R.E., M. Maharaj and R.D., Chapman (2006). Maize yield estimation. Water Research Commission, Pretoria, RSA, WRC Report 1489/1/06, Section 16.2.

Singh, D and H. Singh (2012). Effect of phosphorus and zinc nutrition on yield, nutrient uptake and quality of chickpea. Ann. Pant Soil Res., 14 (1): 71-74.

Skwierawska, M., L. Zawartka and B. Zawadzki (2008). The effect of different rates and forms of sulphur applied on changes of soil agrochemical properties. Plant Soil Environ., 54 (4): 171-177.

Stamford, N.P., A.D. Freitas and C.E. Santos (2002). Effects of rock phosphate, sulphur with and without Acidithio bacillus and organicby products on chickpea (Cicer arietinum L) grown in a Brazilian tableland soil. Trop. Grass., 39: 54-61.

Swarup, A. (2002). Lessons from long term fertilizer experiments in improving fertilizer use efficiency and crop yields. Fertilizer news, 47 (12): 59-73.

Syers, J.K. and A.E.J. Curtis (2008). Efficiency of soil and fertilizer phosphorus use: Reconciling concepts of soil phosphorus behavior with agronomic information. FAO, Vienna.

Egyptian J. Desert Res., 67, No. 2, 305-318 (2017) 
Tondon, H.L. and D.L. Messick (2007). In "Practical of Sulphur Guide". The Sulphur Institute, Washington, D.C., pp. 1-2.

Tyree, M.T., T.D. Scherbatskoy and C.A. Tabor (1990). Leaf cuticles behave as asymmetric membranes: Evidence from measurement of diffusion potentials. Plant Physiology, 92: 103-109. 


\section{تأثير الفوسفور والكبريت على إنتاجية الحمص تحت ظروف الوادي}

حسام الدين أحمد ثابت شومان

وحدة المحاصيل، قسم الإنتاج النباتي، مركز بحوث الصحر اءو، المطرية، القاهرة

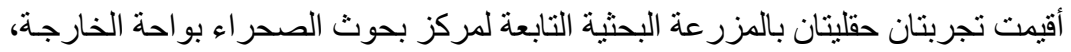



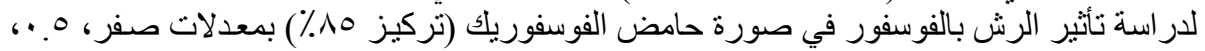

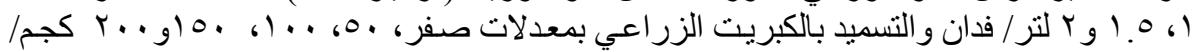

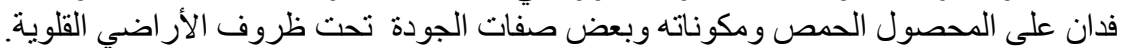
وكانت النتائج المتحصل عليها كالتالي:

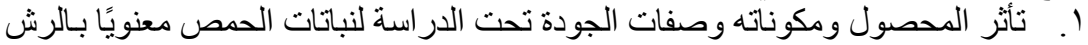

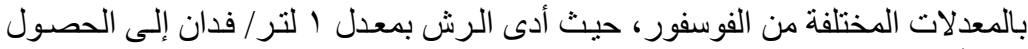

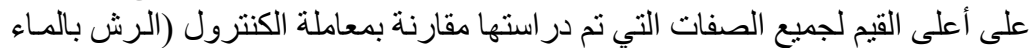

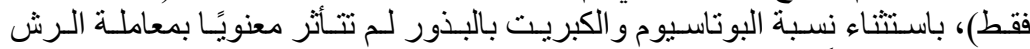

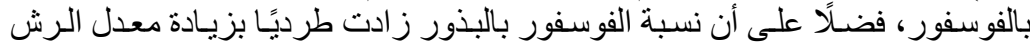

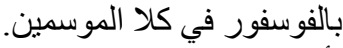

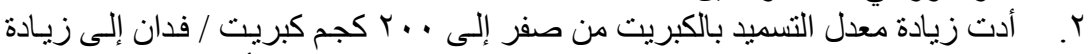

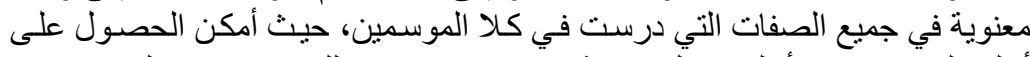

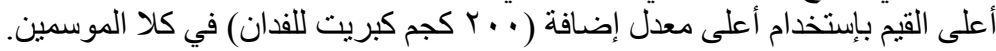

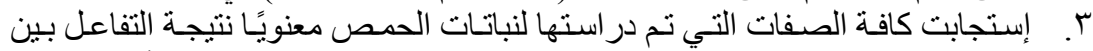

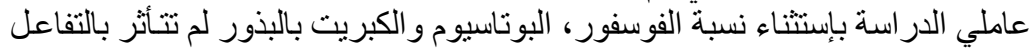

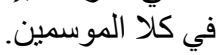

ع. توصي الدر اسة برش نباتات الحمص المنزر عة بالأر اضي القلويـة بمعدل ( لتر / فدان

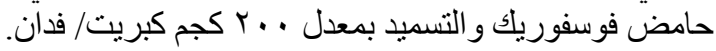

Egyptian J. Desert Res., 67, No. 2, 305-318 (2017) 